\title{
Transvers Myelitis Due to HSV-2 Infection in an Undiagnosed HIV Positive Patient
}

\author{
Tanı Almamış HİV Pozitif Hastada HSV-2 Enfeksiyonuna Bağlı Transvers Miyelit
}

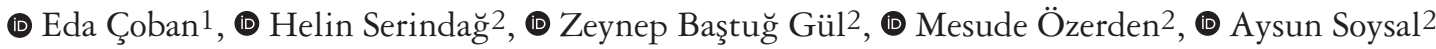 \\ 1 University of Health Sciences Turkey, Bagcilar Training and Research Hospital, Clinic of Neurology, Istanbul, Turkey \\ 2University of Health Sciences Turkey, Prof. Dr. Mazhar Osman Mental and Neurological Diseases Training and Research Hospital, Clinic of \\ Istanbul Neurology, Istanbul, Turkey
}

\begin{abstract}
Several disorders including inflammatory, ischemic, and metabolic can cause longitudinally extensive transverse myelopathy. HIV-associated spinal cord involvement is rare. It can be due to AIDS-associated myelopathy, or opportunistic infections such as cytomegalovirus and herpes simplex virus (HSV). Herein, we describe a 49-year-old man who presented with acute paraparesis and urinary retention. His spinal magnetic resonance imaging revealed extensive hyperintense signal in the long TR sequence throughout C2 to T12, especially in the posterior and lateral columns. Both HIV ELISA test and HSV-2 DNA polymerase chain reaction were positive. Despite treatment, his clinical condition deteriorated. Acute transverse myelopathy can be the initial manifestation of an asymptomatic undiagnosed HIV positive patient. Viral serology reveals the opportunistic infections underlying the disease thereby guiding therapeutic regimens.
\end{abstract}

Keywords: Herpes simplex 2, HIV, myelitis

$\ddot{O} \mathbf{z}$

Enflamatuvar, iskemik ve metabolik çok sayıda hastalık longitudinal uzun segment transvers miyelite neden olabilir. HIV enfeksiyonuna bağlı spinal tutulum nadirdir. Tutulum, AIDS ilişkili miyelopati ya da sitomegalovirüs ve herpes simpleks virüsü (HSV) gibi firsatçı enfeksiyonlara bağlı gelişebilir. Olgumuz paraparezi ve üriner retansiyon kliniği ile başvuran 49 yaşında bir erkek hastadır. Hastanın spinal görüntülemelerinde özellikle posterolateral bölgede C2-T12 segmentleri arasında uzanan longitudinal geniş miyelopati tespit edilmiştir. HIV-ELISA testi ve HSV-2 DNA polimeraz zincir reaksiyonu pozitif saptanmıştır. Uygulanan medikal tedaviye rağmen hastanın kliniği progrese olmuştur. Akut transvers miyelopati, henüz tanı konmamış HIV pozitif bir hastada ilk bulgu olarak karşımıza çıkabilir. Viral seroloji altta yatan hastalığa bağlı fırsatçı enfeksiyonları tanımada ve uygulanacak tedavi kararında yol gösterici olacaktır.

Anahtar Kelimeler: Herpes simpleks 2, HIV, miyelit

\section{Introduction}

Longitudinally extensive transverse myelopathy (LETM) describes the condition of a hyperintense spinal cord lesion extending over three or more vertebral levels on sagittal T2weighted magnetic resonance imaging (MRI). Although neuromyelitis optica spectrum disorder (NMOSD) is among the most frequent causes worldwide, several other disorders including inflammatory, ischemic, and metabolic can manifest as LETM over time (1).
HIV-associated neurologic syndromes are diverse and usually diagnosed at advanced stages of the disease. However, neurologic involvement can also occur at the early stages of the infection, making the diagnosis challenging (2). Approximately $10 \%$ patients present with neurologic symptoms as their initial symptoms. The most common cause of spinal cord disease in HIV-positive patients is AIDS-associated myelopathy, with a reported prevalence of $20 \%$ to $55 \%$ in different series. Other causes of myelopathy in HIVpositive patients include opportunistic infections, neoplasms, and

Address for Correspondence/Yazışma Adresi: Eda Çoban MD, University of Health Sciences Turkey, Bagcilar Training and Research Hospital, Clinic of Neurology, Istanbul, Turkey

Phone: +90 5054834377 E-mail: eda_coban@yahoo.com ORCID: orcid.org/0000-0001-5894-7318

Received/Geliş Tarihi: 08.01.2020 Accepted/Kabul Tarihi: 07.01.2021

${ }^{\circ}$ Copyright 2021 by Turkish Neurological Society

Turkish Journal of Neurology published by Galenos Publishing House. 
vascular lesions (3). Myelitis related to herpes simplex 2 (HSV-2) is a rare entity and mostly reported in patients with malignancy and acquired immune deficits (4).

Herein, we report a case of an undiagnosed HIV infection presenting as long extensive transverse myelopathy due to HSV-2 infection.

\section{Case Report}

A 49-year-old man presented with a 2-month history of progressive bilateral symmetric weakness in the lower limbs, associated with pain, hypoesthesia, and urinary retention. A neurologic examination revealed diminished motor strength in the lower extremities (grade 4/5), hypoactive deep tendon reflexes, reduced tactile and pain sensations below T10, and bilateral plantar responses. No cognitive dysfunction was noticed. The cranial nerve examination was normal. He had no unprotected sexual affair, no history of drug abuse, blood transfusion or past surgical procedures.

Cerebral MRI showed non-specific subcortical hyperintensities with no contrast agent enhancement (Figure 1). However, spinal MRI revealed extensive hyperintense signal in the long TR sequence throughout $\mathrm{C} 2$ to T12, especially in the posterior and lateral columns (Figure 2, 3).

He was admitted to the clinic with a diagnosis of LETM. Routine laboratory data were normal including vasculitis tests, vitamin B12, and copper levels. Syphilis serology was negative in blood and cerebrospinal fluid (CSF) samples. His CSF examination revealed 10 leukocytes, normal glucose $(57 \mathrm{mg} / \mathrm{dl})$, protein $(45$ $\mathrm{mg} / \mathrm{dl}$ ) levels, and $\mathrm{IgG}$ index. Bacterial and fungal cultures were negative, and oligoclonal band type 2 was present. HIV ELISA

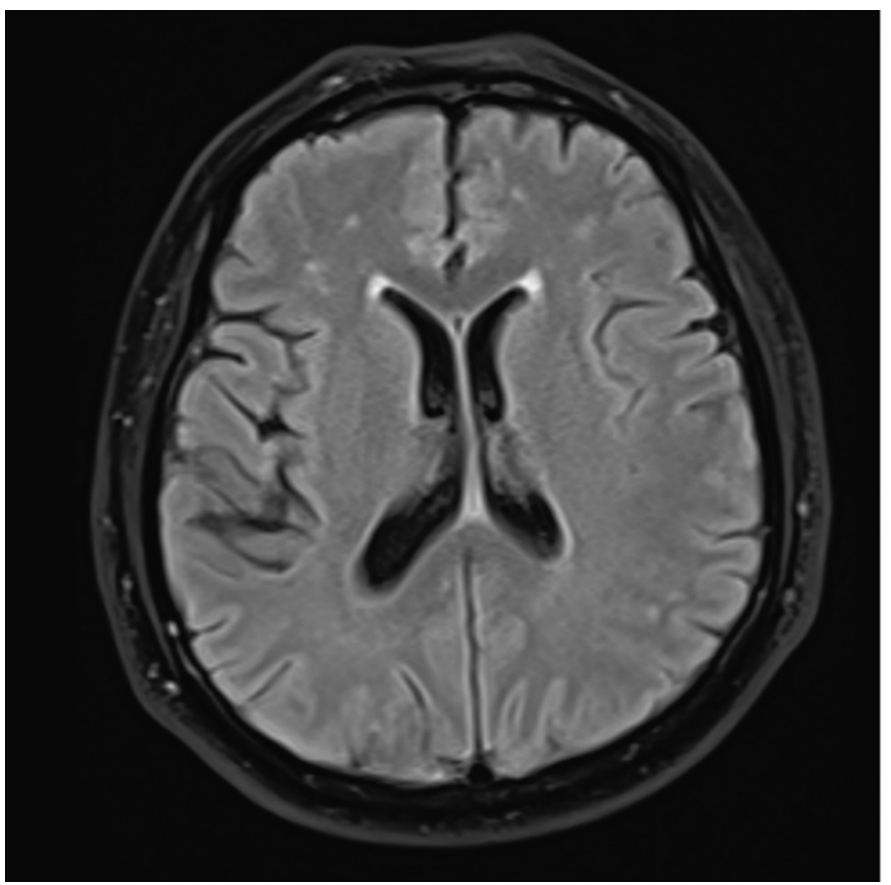

Figure 1. Non-specific hyperintense lesions in FLAIR sequence of cranial MRI

FLAIR: Fluid-attenuated inversion recovery, MRI: Magnetic resonance imaging test returned as positive. Confirmatory tests performed for HIV were positive, CD4 + T-cell count was 44/ul, and his CD4/CD8 ratio was 0.05 . Also, HSV-2 DNA was detected using polymerase chain reaction (PCR) in CSF. Treatment with intravenous acyclovir
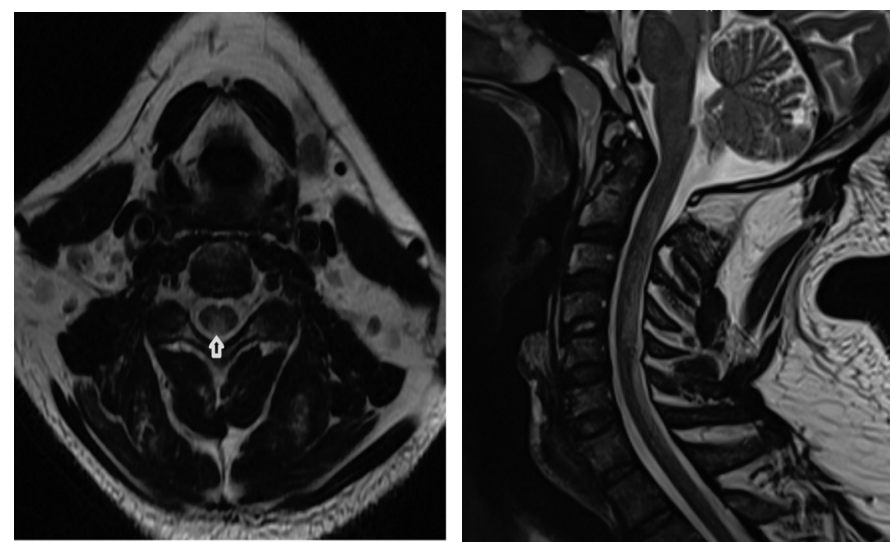

Figure 2. Cervical spine T2-weighted MRI sequence showed a hyperintense lesion

MRI: Magnetic resonance imaging
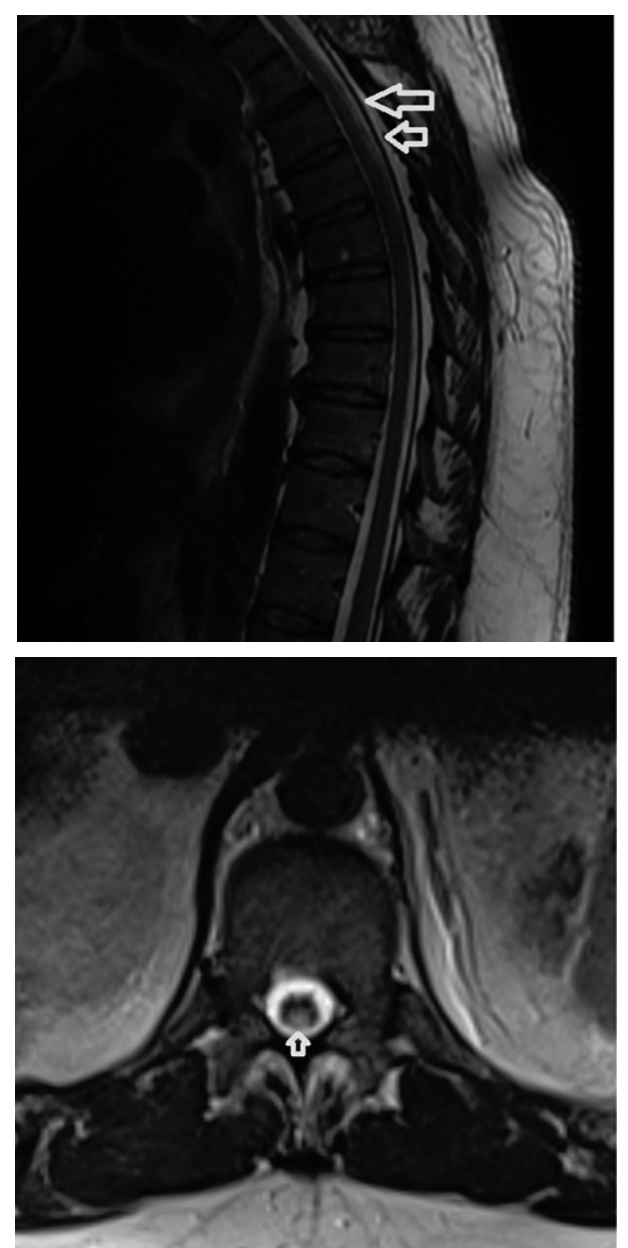

Figure 3. Thoracic spine T2-weighted MRI sequence showed a hyperintense lesion

MRI: Magnetic resonance imaging 
(10 $\mathrm{mg} / \mathrm{kg}$ body weight three times daily) was started and methylprednisolone ( $1 \mathrm{~g}$ IV daily) was also added for inflammatory therapy because some authors assumed that this treatment was the mainstay for attenuating immune-mediated damage and halting further disease progression (5).

Over the following days, upper limb weakness and cranial nerve involvement occurred. On the $6^{\text {th }}$ day of the treatment, dysphagia and nausea were observed. A follow-up diffusion MRI was performed, which showed an acute bulbar infarct that was a complication of the infectious process affecting the central nervous system (CNS) (Figure 4). His clinical condition deteriorated immediately, he had respiratory distress and was transfered to the intensive care unit.

\section{Discussion}

Differential diagnosis of an acute transverse myelitis is broad and might include compressive, vascular, immune-mediated, and infectious etiologies. The initial evaluation should focus on excluding compressive causes (6). Using early MRI we excluded the compressive etiologies in our patient. Also, an ischemic etiology was excluded because the extent of longitudinal expansion of the lesion did not fit into the concept for vascular supply of the spinal cord. Copper, vitamin B12 deficiency, and syphilis were also excluded by blood samples because the lesion was on the posterolateral column of the spinal cord. We performed a lumbar puncture to distinguish an inflammatory condition from a non-inflammatory one. CSF revealed 10 leucocytes with normal glucose and protein levels. However, HIV ELISA test was positive and HSV-2 DNA was detected using PCR in CSF. These findings supported the infectious etiology of the case.

An autoimmune demyelinating disorder of the CNS; NMO is also in the differential diagnosis of LETM. It involves three or more vertebral segments and recurrent episodes of optic neuritis $(7,8,9)$.

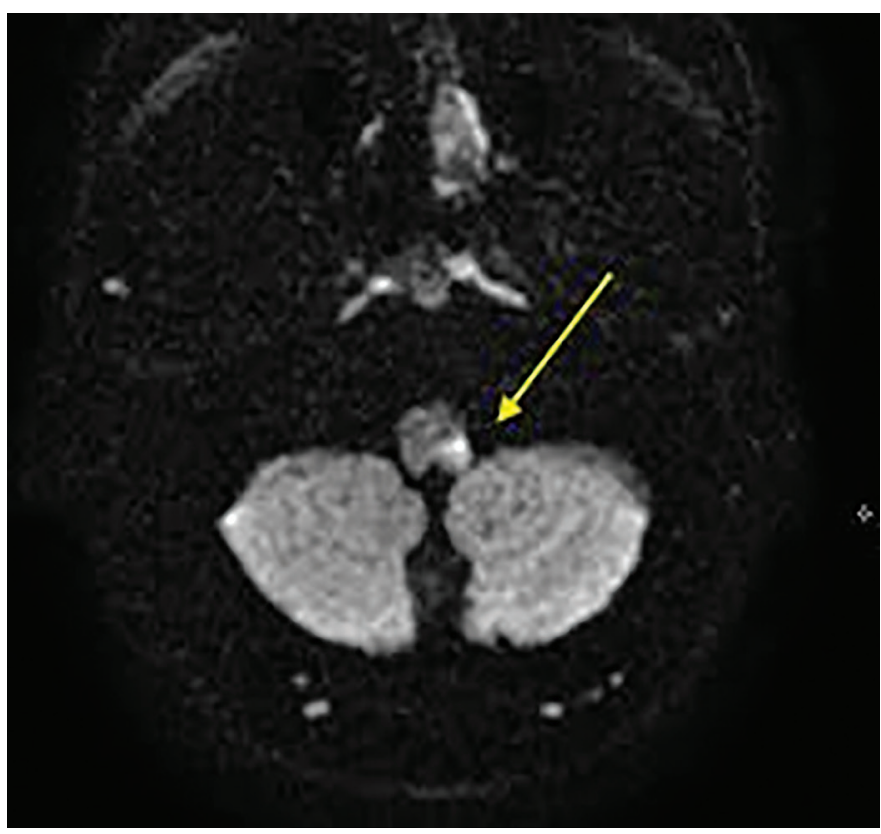

Figure 4. An acute bulber infarct
The presence of AQP4-Ab confirms the diagnosis of NMO with $100 \%$ specificity. Both organ-specific and non-organspecific autoimmune disorders (e.g. systemic lupus erithematosus, rheumatoid arthritis, antiphospholipid antibody syndrome, Sjögren's syndrome) are associated with NMO in up to $20 \%$ to $30 \%$ of patients $(10,11)$. In our patient, we could not obtain AQP4 and myelin oligodendrocyte glycoprotein antibodies due to financial reasons but vasculitis biomarkers were in normal ranges. Also, the patient had no history of optic neuritis and his MRI revealed no cerebral lesions suggesting NMO.

In the literature, it is estimated that $40-70 \%$ of HIV-infected patients develop neurologic complications. Viral infections can directly affect the central and peripheral nervous systems or lead to opportunistic infections due to immunodeficiency (12). The most common cause of spinal cord disease in HIV-positive patients is AIDS-associated myelopathy. The diagnosis of AIDS-associated myelopathy is one of exclusion criteria of other extrinsic or intrinsic processes, such as lymphoma, primary or metastatic neoplasm, tuberculosis, toxoplasmosis, and other opportunistic infections, like HSV, CMV. MRI and serologic tests play an important role in the evaluation of myelopathy in HIV-infected patients (13).

Herpes viruses are neuropathic viruses, which can cause myelitis/ polyradiculopathy, especially in immunosuppressed individuals. In HIV-positive patients, most cases are related to CMV infection, which is also a member of the herpes family. Myelitis due to HSV-2 infection is extremely rare. It is an important cause of encephalitis in neonates. In immunocompromised individuals, HSV-2 can rarely cause encephalitis or myelitis. Any combination of flaccid paraparesis, loss of sensation, urinary retention, constipation, and erectile dysfunction can be observed, as seen in our patient (14). HSV-2 myelitis is assumed to result from virus reactivation, which was latent in dorsal root ganglia, and intraneural spread of HSV2 along the anterior horn over a large area of the cervicothoracic cord (15). A literature search revealed that spinal cord lesions are more frequently located within the thoracolumbar section and genital herpetic skin lesions are found in a few patients. Cervical MRI lesions have also been reported and occasionally in the form of LETM (16). In our patient, the HSV-2 spinal cord lesion was expanding from $\mathrm{C} 2$ to $\mathrm{T} 12$ in the posterior and lateral columns and there were no herpetic skin lesions.

In HIV-positive patients, opportunistic infections in the spinal cord are often observed in advanced stages of the disease, especially when the T CD 4 + cell count is $<50 \mathrm{cell} / \mathrm{mm}^{3}(11)$. In our case, HIV infection was not diagnosed before and the patient was asymptomatic but the CD $4+\mathrm{T}$ count was 44 and it caused an impaired cellular response and enabled it to invade the spinal cord.

Acute LETM is challenging because it presents a broad differential diagnosis. HSV-2 infection is rarely the cause of LETM. When HSV-2 serology is found to be positive in a patient, an immunosuppressive condition should be excluded because it can be the initial manifestation of an undiagnosed HIV infection due to an opportunistic herpes virus. Lumbar puncture and serologic tests will also lead to diagnosis.

\section{Ethics}

Informed Consent: Although the article is a case report, the patient's consent was not taken because the personal identity of the patient was not deciphered. It was learned that the patient died a short time after being transferred from our clinic. 
Peer-review: Externally and internally peer-reviewed.

\section{Authorship Contributions}

Surgical and Medical Practices: E.Ç., H.S., Z.B.G., M.Ö., A.S., Concept: E.Ç., Design: E.Ç., Data Collection or Processing: E.Ç., H.S., Z.B.G., M.Ö., A.S., Analysis or Interpretation: E.Ç., Literature Search: E.Ç., Writing: E.Ç.

Conflict of Interest: No conflict of interest was declared by the authors.

Financial Disclosure: The authors declared that this study received no financial support.

\section{References}

1. Sellner J, Boggild M, Clanet M, et al. EFNS guidelines on diagnosis and management of neuromyelitis optica. Eur J Neurol 2010;17:1019-1032.

2. Koralnik IJ. Neurologic diseases caused by human immunodeficiency virus type 1 and opportunistic infections. In: by Mandell GL, Bennet JE, Dolin R, (eds). Mandell, Douglas, and Bennett's Principles and Practice of Infectious Diseases. Volume 1. 7th ed. Philadelphia, PA: Churchill Livingstone Elsevier; 2010:1745-1764.

3. Chong J, Rocco AD, Tagliati M, et al. MR Findings in AIDS-Associated Myelopathy. AJNR Am J Neuroradiol 1999;20:1412-1416.

4. Widener RW, Whitley RJ. Herpes simplex virus. Handb Clin Neurol 2014;123:251-263.

5. Nardone R, Versace V, Brigo F, et al. Herpes Simplex virus type 2 myelitis: Case report and review of the literature. Front Neurol 2017;8:199.
6. Hauser SL, Ropper AH. Diseases of the spinal cord. In Harrison's principles of internal medicine. Volume 2. 17th ed. In: Fauci AS, Braunwald E, Kasper DL, et al, (eds). United States of America: McGraw-Hill; 2008:2588-2596.

7. Wingerchuk DM, Lennon VA, Pittock SJ, et al. Revised diagnostic criteria for neuromyelitis optica. Neurology 2006;66:1485-1489.

8. O'Riordan JI, Gallagher HL, Thompson AJ, et al. Clinical, CSF, and MRI findings in Devic's neuromyelitis optica. . J Neurol Neurosurg Psychiatry 1996;60:382-387.

9. Lennon VA, Wingerchuk DM, Kryzer TJ, et al. A serum autoantibody marker of neuromyelitis optica: distinction from multiple sclerosis. Lancet 2004;364:2106-2112.

10. Iyer A, Elsone L, Appleton R, et al. A review of the current literature and a guide to the early diagnosis of autoimmune disorders associated with neuromyelitis optica. Autoimmunity 2014;47:154-161.

11. Boissé L, Gill MJ, Power C. HIV infection of the central nervous system: Clinical features and neuropathogenesis. Neurol Clin 2008;26:799-819.

12. Whiteman MLH, Post MJD, Sklar EML. Neuroimaging of acquired immunodeficiency syndrome. In: Berger JR, Levy RM, (eds). AIDS and the Nervous System. 2nd ed. Philadelphia: Lippincott 1997;297-381.

13. Baringer JR. Herpes simplex infections of the nervous system. Neurol Clin 2008;26:657-674.

14. Kennedy PG, Rovnak J, Badani H, et al. A comparison of herpes simplex virus type 1 and varicella-zoster virus latency and reactivation. J Gen Virol 2015;96:1581-1602.

15. Kyllerman MG, Herner S, Bergstrom TB, et al. PCR diagnosis of primary herpesvirus type I in poliomyelitis-like paralysis and respiratory tract disease. Pediatr Neurol 1993;9:227-229.

16. Griffiths P. Cytomegalovirus infection of the central nervous system. Herpes 2004;11:95-104 